\title{
The German Social Market in the World of Global Finance: Pension Investment Management and the Limits of Consensual Decision Making
}

\author{
Gordon L Clark, * Daniel Mansfield\# and Adam Tickell\# \\ *School of Geography and the Environment, and Said Business School, \\ Mansfield Road, University of Oxford, Oxford OX1 3TB \\ \#Department of Geography, University of Bristol, Bristol, BS8 1SS \\ contact gordon.clark@geography.ox.ac.uk (draft $1^{\text {st }}$ August 2000)
}

\begin{abstract}
In a previous paper we emphasised the changing national and international accounting standards used to measure net pension liability. Beginning with the implications of this analysis for the financing of German employer-sponsored pensions, in this paper we focus upon the internal management of corporate pension assets and liabilities. Two issues drive the analysis. One has to do with the emerging coalescence of interests joining corporate management and shareholders in relation to the management of pension assets and liabilities. The second issue has to do with the allocation of risk and uncertainty between social partners when negotiating the financing and final value of promised retirement income. We analyse the importance of workers' risk aversion and the widely-held goal of stable long-term real incomes for the management of pension assets. In the context of global financial markets, we suggest that the institutional framework of investment decision making common to many of Germany's largest firms is under considerable pressure; three models of investment decision making relevant to pension assets and liabilities are used to illustrate this point. Contrasts are drawn with competing systems of corporate governance, noting the incorporation of pension financing into Anglo-American corporate treasuries. Implications are drawn with respect to the changing status of German employer-sponsored supplementary pensions in relation to debate over the future of social security and social insurance.
\end{abstract}

Acknowledgements. Research for this paper was supported by AIG Financial Products Corp. (London), the Future Governance programme of the UK Economic and Social Research Council, and the University of Oxford. We would like to thank Robert Hirst and Joe Cassano from AIG, and Ed Page from the Future Governance programme. In large part, this paper is based upon interviews with many industry respondents in the UK and continental Europe. While most have requested anonymity, we should record our appreciation for the help provided by John Gillies, Ulrich Jurgens, Karl Stieferman, Christian Urbisch and Harry Wolf. Jan Burke expertly processed and re-processed the manuscript and Jane Battersby and Zoe Morrison provided able research assistance. None of the above should be held accountable for the views expressed herein. 


\section{Introduction}

Pension policy has been widely debated in Germany (Rurup 2000). Notwithstanding adverse demographic and fiscal trends (Disney 2000), policy initiatives have often stalled-caught between a commitment to comprehensive but largely unfunded social insurance and a reluctance to introduce the tax incentives that would promote private pension provision. At one level, the issues are entirely political and deeply embedded in domestic social affairs having to do with the role of social insurance as a force for social cohesion. At another level, however, these issues have enormous importance for the future of German industry in the global economy. Inevitably, any effective proposal for encouraging the private provision of pensions must deal with the cost to capital, recognising the existing high social costs of labour relative to international competitors. Resolution of these economic and political tensions has been identified by the financial community as an important test of German political capacity in the light of globalisation (Deutsche Bank 1999, pp. 27-30).

In a previous paper, we looked closely at the imperatives driving German corporate pension policy (Clark, Mansfield, and Tickell 2000). It was suggested that the adoption of international accounting standards modelled on Anglo-American pension accounting rules could have far-reaching implications for the provision of German supplementary pensions. We noted that net pension liabilities are significant for many large German corporations in absolute and relative terms compared to Anglo-American competitors. Net pension liabilities also vary considerably by industry sector and firm financial indicators like total financial liabilities and gross revenue. By virtue of this information on "unfunded" direktzusagen (book reserve) and "under-funded" pensionskassen (mutual insurance) defined benefit pension systems, their corporate sponsors have been put into "play" in financial markets. Consequently, questions can be raised about the long-term viability of direktzusagen pensions systems. Even if these systems were important for the financing of post-war economic growth, and even if these systems were important in binding together the interests of successive generations of firms' workers and management, global capital markets may not appreciate these virtues when "pricing" German firms.

Left unanalysed in the previous paper were the implications of adopting international accounting standards for the governance of German firms. We could assert that market imperatives will, in the end, drive through "local" corporate relationships and governance practices towards the most efficient "global" solution. This view denies the relevance of corporate decision-making, supposing that autonomous market agents promote efficient 
corporate forms and functions (Easterbrook and Fischel 1990). If compelling as a matter of theoretical logic, it is empirically problematic. In any event, any corporate response to market imperatives is inevitably conditioned by inherited institutions and relationships as well as opportunism. To think otherwise is to claim too much in the face of history and geography (see Clark 1994 and Bebchuk and Roe 1998). On the other hand, we must take care not to idealise inherited corporate form and function-as we suggested in relation to the adoption of IAS 19 and FASB 87 (US GAAP), corporate management may defect from established customs and relationships. In this paper, we explore the implications of adopting international accounting standards for the governance of large German corporations (in general) and their supplementary pension institutions (in particular).

To do so requires, in the first instance, a brief review of the various modes of German corporate retirement income provision. This takes us from summary data regarding coverage rates through to the role and status of direktzusagen and pensionskassen pension systems in the context of German labour-management relations and collective bargaining (codetermination). Little of this material will be new to experts in the field. But it is important to set-out the nature of inherited institutions and practices, recognising that our analysis in latter sections of the paper takes aim at these remnants of past struggles over the balance of power within and between firms. Not only do these institutions and practices reflect the foundations of post war power sharing and economic growth, they are often legitimated by reference to idealised conceptions of German society. In our analysis of corporate governance we introduce a set of economic imperatives and management interests that challenge continuity with the past. Globalisation and the promise for management of stock options geared to the market value of the firm are our "threats" to the past while inherited institutions and practices are our "constraints" on collective decision-making.

Sustaining the paper is a series of linked arguments that cumulate to an overarching position on the disputed tension between globalisation and localisation. To start we argue that German employer-sponsored supplementary pensions are more important than often acknowledged; coverage rates are comparable with the Anglo-American world and promised benefits may be a significant component of retirement income. Further more, we suggest that many large German firms have extensive experience with Anglo-American pension benefit systems, providing valuable insights into the advanced management of assets and liabilities not readily available to their workers or most other German firms. The available evidence on behaviour seems to suggest that German co-managed pension institutions tend to satisfice 
rather than maximise or optimise; unfunded or under-funded net pension liabilities are, unfortunately, associated with management regimes that have as their primary goal consensus given workers' risk aversion. ${ }^{\mathrm{i}}$ Even so, this regime is under threat from German managers concerned to enhance their long-term wealth rather than their share of corporate income. Continuity with the past is vulnerable to defection and the interests of market agents operating in global financial markets.

Some points about methodology should be made at the outset. In the first instance, the paper relies upon accumulated intensive fieldwork and interviews in Germany, continental Europe, the UK and the US. As such, points of contrast between systems of corporate governance are built-up from knowledge of specific circumstances; compare Clark (1998) with La Porta et al. $(1998 ; 2000)$ who use broad statistical studies of countries' legal and financial regimes. ${ }^{\text {ii }}$ Secondly, this kind of inductive methodology is as much a means of representing the world of large German firms as it is a device for developing informed theoretical perspectives on current trends. As much as we admire the analytical clarity of financial theorists such as Myers (2000), it is hard to accept the argument that "the modern financial environment is too complex and varies too much from country to country to support ready induction of underlying principles" (p. 1006). Still, our analysis should be understood as suggestive rather than definitive. We would be cautious of extending our analysis to smaller closely-held German firms even if we doubt the strong claims made by Kluth and Andersen (1999) about the distinctiveness of that domain.

Finally, rather than document our points by referencing specific interviews, the argument progresses by successive moves of analytical complication. We begin with an argument about the role and status of German corporate pensions and then move on to various forms of decision making that allow for contrast and differentiation. In this sense, we remain interested in Myers' models of corporate organization as useful ways of conceptualising argument even if we remain slightly puzzled by his claims of methodological purity.

\section{Social Insurance and Supplementary Pensions}

For analysts focused on reform of social insurance, the German retirement income system is believed to have a number of virtues. Being comprehensive in coverage with benefits proportional to workers' income, the social insurance system provides a level of retirement income that is arguably equitable within and between successive generations. ${ }^{\text {iii }}$ As well, the 
system provides related disability, early retirement, surviving spouse and family benefits. By comparison, many would argue that employer-sponsored supplementary pensions are irrelevant. For instance, some suggest that any policy aimed at encouraging supplementary pensions would not, and could not, make a significant difference to the financing of social insurance. Older workers, the generation who dominate the expected long-term PAYG financial burden, would not be able to accumulate sufficient assets to be able to retire with incomes equal to the promised benefits of the PAYG system. And younger workers, who might benefit from the enhancement of supplementary private pensions, may have to pay twice: for the retirement costs of their parents and for contributions to their own retirement accounts. In any event, or so the argument goes, coverage rates are low, benefits are limited, funding is inadequate, and expected benefits risky.

\section{Social market and private pensions}

If we take this logic seriously, the priority attributed to social insurance is under-scored by the structure of the German "social market": the inter-related institutions of collective welfare, finance and governance that together, according to many commentators, differentiates Germany from the Anglo-American world. See Hutton (1995, p. 20) where he compared various countries arguing that "the behaviour of the economy can only be understood in terms of the whole of each country's social and political system and where it stands in the global order." All this is well appreciated in the academic literature, being the staple diet of comparative corporate governance and the idea that nation-states are persistently "different" by virtue of their internal organization (history and geography) (see Hopt et al. 1999). Perhaps less appreciated is the extent to which the social market is under threat from "insiders" and the changing global economic environment. An exclusive focus upon social insurance would seriously under-estimate the changing status of employersponsored supplementary pensions.

For analysts familiar with German economic and social policy, the social market is a comprehensive system of interdependent and reciprocal systems of governance. Each system of governance, like the social insurance system, relates in a concomitant manner to the other parts of the whole system. In combination, these systems of governance add-up to a comprehensive and coherent web of self-sustaining institutions and practices. This structureoriented view of German society is more than the just an empirical observation; it can be found as a theoretical argument in its most developed form in Luhmann's (1995) treatise on 
social systems. By his account, social systems are self-referential systems of governance that together constitute the whole while regulating relationships between the constitutive elements. If social systems are properly thought to be the products of agency (action) and contingency (events), in the German case the social system is knitted together by reciprocal relationships and collective deliberation. So, for instance, the role and status of collective bargaining is at once determined by an ideal conception of the proper relationship between management and labour in society and the need for dispute resolution relevant to the immediate circumstances of industries and firms. ${ }^{\text {iv }}$

Echoing this logic, Reynaud (2000,4) suggests that commitment to German social insurance reflects the "network of various contacts and multiple forms of cooperation between the social partners and the government." Cooperation on this issue is believed to sustain cooperation at other points in the system of mutually reinforcing economic, social and political systems. Reynaud goes further, and perhaps beyond Luhmann's theoretical enterprise, to suggest that social insurance has a distinctive status in German society. Any forced change in its status, bowing to global market imperatives and the interests of private agents, would be detrimental to the integrity of related systems of industrial and social governance. In this model, private pensions are deemed outside the parameters of the social market. This is despite the fact that about 45 percent of the workforce are "covered" by supplementary schemes albeit true that coverage is biased towards public employees and employees of large firms rather than small firms (see Queisser 1996).

Data on German supplementary pensions are difficult to obtain. Nevertheless, the available evidence suggests that these types of pensions are more important than often believed. Koenig and van der Lende (1999, p. 5) have noted that about 32 percent of firms offer supplementary pension benefits and, most significantly, 87 percent of firms with more than 5,000 employees offer such benefits in their compensation packages. ${ }^{\mathrm{V}}$ Furthermore, many large corporations have had supplementary pension systems for many years, stretching back through the twentieth century. In terms of value, major German corporations have developed pension systems that now contribute a significant share of retirement income. See, for example, Table 1 comparing the value of pension benefits across industrial competitors. Of the nine firms identified in the table, all firms sponsor plans that contribute 20 percent or more to final retirement income. In most cases, firms bear the burden of contributions, and even when they do not employees' share is small. For many large firms and their employees, private pension provision will be of greater importance if proposals designed to cap the value 
of social insurance benefits effectively shift the burden of income replacement to private institutions and individuals. ${ }^{\text {vi }}$

\section{Social systems and the environment}

Implied by the structure-oriented argument is a certain relationship between social systems and their environments. For Luhmann, social systems are organically related to their environments. Although conceived as a passive "correlate" of the social system, the environment is nevertheless a constitutive element of the social system by virtue of its relative complexity. Accordingly, social systems are made coherent by what is deliberately excluded from those systems recognising that coherence requires the exclusion of anything that would directly challenge the integrity of the whole. Hence, that which is deliberately excluded is left unincorporated and "located" in the surrounding environment. In this respect, Luhmann, like many other commentators on the German scene, has suggested that social systems are conceived, in part, in opposition to the apparent dis-order and dis-harmony of the market economy. Various implications follow from this logic. Most importantly there is an implied hierarchical ordering of institutions and their systems distinguishing between those that are endogenous (for instance, social insurance) and exogenous (for instance, private pensions). Employer-sponsored private pension arrangements may co-exist with social insurance; exclusion is a logical ordering of significance as much as it is a process of lexical distinction.

Even so there is a paradox in theory, and as we shall see, in practice.

Notwithstanding the claimed irrelevance of private pensions such arrangements are inevitably governed by existing overlapping and inter-related social systems even if those systems have as their goal the mediation of endogenously defined social relationships. This is most apparent when considering the governance of employer-sponsored private pension institutions like pensionskassen. Even though these institutions are deemed irrelevant to the core institutions of social insurance, employment law and the collective bargaining system overlap with and dominate pensionskassen. This point is also made by Weiss (1995). Therein he sketches the basic principles underlying federal German law, noting the relationship between labour law (based upon private contract law) and labour-management relations (based upon collective rights). He suggests, in fact, that these two aspects of law are "closely inter-related" (p. 23), just as social security law is "closely inter-related" with labour 
law (p. 24) even if each system is "strictly separated" (p. 24). More specifically, social security law is a branch of public law not private law.

As each social system selects from and responds against its environment, it evolves over time in ways that forge a distinctive relationship to the environment. By this logic, we can go one step further in the argument noted above: as social insurance has evolved in relation to concomitant systems of social organization, private pensions have remained peripheral to German retirement income provision. The implication is plain: the effect of any new tax incentives designed to promote private pension provision will be muted because of the continued significance of otherwise dominant inter-related social systems. This is, yet again, another version of path dependence and institutional persistence (so important in economic geography and comparative corporate governance). Even so, we should not exaggerate the significance of path dependence. Although social systems tend to exclude incompatible institutions, or relegate them to the margins of existing institutions, this is not surely an absolute process. Rival modes of social organization may lie dormant or function within the shadows of existing systems of governance. Likewise, the process of selection within and without social systems is surely a contested political process. Social agents may call upon excluded or marginal modes of social organization as weapons in attempts to redefine their relationships to social systems.

For theorists of social systems, evolution is thought of as a process of selection and adaptation in relation to changing circumstances (Luhmann 1995, 433). Systems immediately affected pass-on their response to change to other inter-related systems, being a cumulative process of incremental accommodation even if the end result may be less predictable than the immediate effects of changing circumstances. If this appears to be a rather benign process, it is because it presumes the continued integrity of the whole. But there are reasons to suppose that recent changes in the environment of German social systems are neither incremental nor benign in effect. Three points can be made summarising this claim.

First, the environment in which German social systems and social agents operate has begun to change scale, a process described by Swyngedouw (2000) as "re-scaling of the economy". While the nation-state remains important for most firms and the social partners, the international economic environment has become more important than ever introducing new imperatives and circumstances not previously encountered or incorporated into post-war German social structure. At the same time as economic up-scaling has come to be important, 
down-scaling in terms of the effective unit of response (from industry to firm, and from social partners to management) to these imperatives has become important. Collective institutions, the bedrock of German co-determination, may be "at risk" in this new order.

Second, both large German firms' management and nation-state elites have an interest in responding to these imperatives. The former are engaged in competition for global position while the latter have claimed the opportunity to provide economic and political leadership in Europe and beyond. Both have an interest in creating national champions, competitive in the global economy. Whereas Luhmann and others suppose that social systems evolve by balancing interests and by reflexive responses to changes in inter-related systems, these types of responses may be too slow relative to the speed of globalisation or too cumbersome in the light of changed priorities. In play is the historical pattern of inter-related social systems in the light of claims about what is now relevant for the global rather than the national environment.

Third, whereas institutions and practices like employer-sponsored pensions were once considered peripheral to core social systems and were relegated to a marginal status, as globalisation accelerates these institutions may be especially important even if their integrity is threatened by the imperatives driving global finance. In effect, and notwithstanding the particular formation of German financial institutions with German social systems, AngloAmerican financial practices now threaten to under-mine both German banking practices and the coherence of inherited relationships between the systems of finance, labour and retirement income provision.

\section{German Corporate Structure and Governance}

To comprehend the significance of the social market for corporate pension policy, and factorin the implications of large firm strategy in the context of globalisation, requires a series of analytical moves designed to elucidate the structure and logic of decision making. In this section we begin with an idealised model of German corporate structure relevant to inherited systems of decision making. In subsequent sections, we introduce global complications in order to show the inter-action between re-scaling and corporate pension management and investment decision-making. Here we begin by setting-out general assumptions about the role and status of intentional and rationality. It should be apparent that we do not accept the assumption made in much of the finance literature that economic and social agents are so profoundly rational that the existence of rational expectations obviates the need for an 
analysis of the process of decision making. On the other hand, we would also assert that decision making is an ordered process; "irrationality" is less the issue than the structure of decision-making (see Clark 2000 for a worked-through set of examples relevant to the AngloAmerican world of pension fund investment decision making).

\section{Behavioural assumptions}

Economic theory is largely silent on the related issues of consciousness and intention (Biccieri 1993). For some theorists, it is enough to assume people naturally are utility maximisers. By this one assumption complex matters of deliberation and planning are resolved at a stroke of the pen. It does not matter how people assess their options and it does not matter what their plans are in relation to their options; what matters is the application of the golden rule to different circumstances. If some people deviate from the best path of action, it is assumed that market imperatives provide sufficient discipline to limit systematic departures from this logic (if not practice). Those who are systematically "irrational" could not and would not survive (economically speaking). Amendments can be made to this logic that seem to recognise the world as we know it even if nothing really changes in the underlying theoretical edifice. For example, it could be noted that people rarely have sufficient information to act in an entirely error-free manner, and it could be noted that there are limits to the value of processing information. A variety of arguments can be made about the costs and benefits of approximation and the virtues of learning-by-doing.

This characterisation is, admittedly, crude. It focuses upon conventional theorising at the expense of attempts to re-make economic decision making with a psychological core (Camerer and Weber 1992). Even so, in much of the literature a binary distinction is made between rational (good) behaviour and non-rational or irrational (bad) behaviour. For those with a clear, uncluttered conception of rationality the concept is thought to refer to action that has an unequivocal connection between means and ends. By definition, to be rational means choosing the best means to achieve the most desired end. On the face of it, the value of this kind of proposition may be judged empirically: we could set a test of the veracity of the proposition. But this is less important here than the fact that binary models of rationality are universal in their application; it does not matter if economic agents are American, British or German-the logic applies or should apply if institutions are sufficiently benign (as they should be). 
In this paper we take three steps away from this conventional logic. In terms relevant to the German context we assume the following conditions. (1) Desired goals often depend upon the context in which actions are contemplated; (2) available means to ends are, more often than not, also affected by context, and; (3) there may be good reasons for acting consistently within a given context just as there may be reasons for defecting from the norms that define that context. ${ }^{\text {vii }}$

\section{Economic agents as stakeholders}

Much of economic theory is focused upon economic agents with thin social roles. That is, economic agents are individuals with utility functions that happen to occupy certain positions and spaces in institutions and society. So, for example, individuals may be workers, or managers, creditors or shareholders each with their own goals and objectives. It is also tempting to suppose that each type of economic agent has a set of common goals and objectives being, in effect, more similar within the type than between types once we suppress details of individual interests. While we can begin with individuals in their own right, the next move would be to show how and why they may be summed together under distinct headings (like worker etc.). See Baird and Picker (1991), for example, where they use a Creditor and a Manager to represent competing corporate interests. Of course, the process of summing-up to a "representative" agent involves arguments about the nature and scope of cooperation and collective action, topics that dominate the literature on bargaining and negotiation; witness the significance attributed to game theory (see Binmore and Dasgupta 1987 on Nash bargaining).

We also use the analytical device of the representative agent: introducing workers, managers, and shareholders. And we introduce a related agent called banker to help the analysis along. But we do so recognising that these categories have particular German significance, the product of deliberate attempts to regulate firms' labour-management relations (O'Sullivan 1998). To explain, recall that the standard theoretical move is to sumup individuals into categories and attribute to that category actions and interests that represent their type of person. In our case, however, we should recognise that a worker is a person with social roles nested in a hierarchy of inter-related social institutions. Each worker (for example) is an employee of a firm, and is represented by his/her union on the firm's Works

Council. Each worker is a member of a union, itself affiliated with its parent industry union and the national union organisation, and; each firm and its local union are represented on the 
regional industry council where much of the bargaining over wages and benefits takes place. From the firm through to industry associations, workers and managers sit side-by-side in elected or nominated roles as representatives of their respective constituencies. ${ }^{\text {viii }}$

Joint representation is a common feature of German industrial life though often dependent upon firm size, its industry affiliation and co-determination status. Joint representation does not necessarily translate into common interests or ready agreement over corporate strategy. Nevertheless, we do assume that managers and workers share one basic goal: (4) an over-riding interest in the anticipated growth in the real value of their lifetime earnings. This may be portrayed as a zero-sum game, where workers' share of corporate income is equal to (1-managers' share). More likely, however, workers and managers collude to minimise shareholders' share of income (dividends). Our opinion on this matter is developed in more detail below. We should also note, of course, that the expected growth of lifetime earnings is the product of at least the following: continuity of employment, growth in corporate market share, and higher rates of productivity. Sustaining these conditions requires the cooperation of workers and managers. But this does not mean that workers and managers need agree on the strategies for attaining these conditions.

\section{Corporate governance and control}

It is inevitable that we also consider the relationship between shareholders and managers, the classic principal-agent problem that figures so importantly in the Anglo-American literature (Demsetz 1983). We assume, as most theorists of the modern corporation assume, (5) managers have considerable discretion-the power to initiate corporate strategy including investment in plant and equipment subject to periodic review by shareholders. In the AngloAmerican world, corporate management has considerable room to manoeuvre because of the dispersed nature of share ownership. Not only is it difficult to monitor manager actions, imposing discipline is quite problematic. While it can be contended that Anglo-American managers are vulnerable to their firm's share-price volatility, few managers are ever actually held accountable except in the most extreme circumstances (Bliss and Flannery 2000). Amongst large German firms, of course, share ownership is often quite concentrated and dominated by firms and financial institutions that hold one-another's stock (cross-holdings). This has been widely documented, and is an aspect of German corporate structure that draws the bulk of commentary from inside and outside of Germany. ${ }^{\text {ix }}$ 
Whereas considerable academic attention has focused upon the supervisory boards of large German firms, firms' management boards are often closer to corporate decisionmaking, the control of resources, and the distribution of income between various internal stakeholders. In fact, in many cases there is a presumption in favour of the management board as the operating core of firms. By contrast, the supervisory board should be thought (for the moment, at least) to be an institution of appointment and review rather than of policy initiation. Just as management boards tend to represent internal stakeholders so too do the management boards of corporate-sponsored and jointly-managed pensionskassen. The structure of governance of these institutions is much like Dutch industry pension funds and many continental corporate pension funds (Bennett and Clark 2000). Boards of management overlap with one-another relying upon agreement at one site (the firm's management board) to manage pension benefits at other sites (including the corporate pension fund board of management). By contrast, direktzusagen pension arrangements tend to be ensconced within corporate treasuries closely controlled by management.

It is widely believed that insider knowledge is a by-product of shareholder dominance, and that it provides participating institutions an advantage over market agents located in global financial markets. We do not dispute this argument directly (empirically). But we do want to suggest that dominance without an exit option is less valuable than is often assumed. For a number of our respondents, the cross-holdings of stocks between related firms and institutions actually limits the power of supervisory boards. There is a strong albeit implicit culture of mutual respect and mutual disengagement with respect to one-another's interests. As a consequence, and notwithstanding the potential power of such boards, supervisory boards are often of secondary functional importance to management boards. Even setting shareholder dividends is highly constrained (see Andre 1998, and Roe 1998). Here our assumption is that (6) large firms' management boards, being the representatives of the interests of internal stakeholders, tend to dominate their supervisory boards, the representatives of external shareholders. Management power is firmly entrenched and rarely directly challenged by supervisory boards. ${ }^{\mathrm{x}}$

These six assumptions, and variations on these assumptions, are important in our analysis of corporate pension policy. Whether they are entirely true across all German industry is less important, at this juncture, than the value of such assumed divisions of interests for the models that guide our understanding. 


\section{Global Learning and Local Strategy}

Many DAX 30 firms operate throughout continental Europe, the UK and North America. Of course, the geographical scope and intensity of external operations varies between firms and industries. By virtue of their merger with Chrysler, Daimler Benz is now deeply immersed in the North American auto market compared, for example, with BMW notwithstanding their own US operations. There is, for many of these firms, a tension between the management of their German operations and their international operations. Simply, the issue is the extent to which management practices within the firm different jurisdictions ought to be resolved in favour of common company-wide practice. For the most part, this issue has been resolved in favour of local practice because management has been required to respect local customs and regulations pertaining to employment and labour relations practices. So, for instance, Gertler (2000) has shown that the application of common production technologies within German manufacturing firms across the world has almost always led to local solutions rather than the application of company-wide standards; the local environment is an important mediating variable.

For German firms, of course, there is a further complication. Not only are many aspects of management practice caught-up within the fabric of inter-related systems of economic and social regulation, those systems are defined, in the first instance, by reference to the German environment rather than other countries' environments or the global environment at large. In fact, many would contend that other countries' environments are not simply at a distance from the German environment but are irrelevant to German social systems. This is surely the argument deployed by those concerned to protect the integrity of the German social market. There are significant barriers to the use of experience in Germany from outside Germany. ${ }^{\mathrm{xi}}$ Even so, for German firms operating in the Anglo-American world the 1990s brought home important lessons regarding the management of employer-sponsored pensions. These lessons were drawn from their own experience, the experience of other German firms, and the experience of their competitors. Here, we focus on three aspects of this experience.

In Table 2, summary data are presented on the numbers and types of pension and retirement income benefit plans operated by leading German firms in the US during 1997 and 1999. This data was accessed through corporate reports to the US Department of Labour (DoL) concerning the funding and investment status of those plans (Form 5500). ${ }^{\mathrm{xii}}$ Notice these plans were almost always fully funded as required by statute, US GAAP and the 
Financial Accounting Standards Board (FASB) (Clark, Mansfield and Tickell 2000). Here, we make three important observations. First, many of the large German firms operating in the US have had extensive experience in the full range of pension and retirement benefits including defined benefit plans, 401(K) defined contribution plans, profit sharing, savings and flexible benefit plans. Second, many German manufacturing firms provided benefit plans in union and non-union environments, thereby having to manage trustee boards with and without employee representatives. Third, even firms with relatively small US operations have had considerable experience with the financial services industry that underpins the US private pension and retirement benefit system (Clark 2000).

Of course, some German firms may have had less direct experience with these types of benefit systems than implied by Table 2. Mergers and acquisitions between German and US firms have not always lead to mutual understanding. But consider, in brief, the (1997) experience of Bayer (Table 3). One of their plans (003) was a DB plan funded by employer contributions on behalf of 336 active workers and about 118 retirees represented by the United Paperworkers Union. During the year, the net rate of return on a base asset market value of $\$ 6$ million was approximately 31 percent. Another plan, a 401(K) plan (019) with more than 18 thousand active participants and about 12 thousand retirees was funded by employer contributions ( $\$ 35$ million). Over the year, the net return on an asset base of about $\$ 1.6$ billion was approximately 19 percent. In this brief comparison is an important story about the evolution of US retirement benefits from DB plans for union members to DC plans for non-union participants. Also embedded in this comparison is a complicated story about who bears the risks of pension liability, the shift towards employee contributions, and the integrity of the investment management process in the context of an accelerating equity boom. We do not wish to belabour these points made so often and in detail elsewhere (Mitchell 1998). Our point is just the recognition of common experience amongst large German firms in the US.

To take this point further, recall that we showed in the previous paper that the (1998) reported expected rate of return on pension assets for US S\&P500 companies was 9.19 percent up from 9.08 percent in 1994. Also recall that a significant number of these firms reported expected rates of return between 9.5 and 10.5 percent. By comparison, our research based upon annual reports for DAX 30 German firms for the same year indicated that the reported expected rate of return on pension assets ranged from 5.5 to 9.7 percent, with most around the 7.0 percent mark. Unfortunately, this data was sparse and of limited quality. 
More detailed were data on the reported discount rate, ranging between 5.5 and 6.5 percent. In effect, German firms expected significantly lower rates of return on their unfunded or under-funded German plans compared to the expected rates of return on their funded US plans. Now, of course, the German situation is quite different than the US situation; for instance, in Germany there are significant quantitative limits on asset allocations by asset classes, biased in favour of bonds against equities (national and international). This has been the subject of considerable debate in Germany and within the European Commission (see NIESR 1997 and De Ryck 1999).

But most important has been the realisation amongst German firms that their AngloAmerican rivals have developed much more aggressive investment strategies. Many US firms have managed investment of their DB pension fund assets so as to decrease their contributions and, in some cases, contribute to their net reported corporate income. This point was made in the previous paper using data from a report by BearStearns (McConnell et al. 1999), and has been subsequently validated by other reports for 1999 by industry analysts (see Towers Perrin 2000 Watson Wyatt 2000) and interviews with UK and US firms. ${ }^{\text {xii }}$ This kind of investment strategy can be characterized as a maximization strategy, using the most advanced financial methods to drive rates of return in a manner consistent with corporate financial objectives. It stands in contrast to the objectives commonly attributed to pension fund management; optimising the value of current assets against expected liabilities (Logue and Rader 1998). Whether German firms operating in the US have developed similar investment strategies is unclear. Given the free-flow of information within the US investment management community, it is very unlikely that corporate management were unaware of these developments.

In Germany, however, pension investment practice is deeply embedded in the institutions of co-determination. Consensus or collective deliberation and agreement drives the investment management process. By necessity, this process reflects a wide variety of interests and objectives shared or not shared between the representatives of corporate stakeholders. By default, satisficing dominates the setting of objectives and the nature of decision-making (see below).

\section{Management Motives and Corporate Governance}

In the preceding section, we showed that over the 1990s large German firms accumulated Anglo-American experience and/or knowledge at odds with German customs and 
conventions. Information was acquired either directly through their overseas affiliates or through analysis of the actions and behaviour of competitors. And if none of these channels worked, their actuarial and investment consultants were more than willing to fill-in the gaps. We have intimated, however, that notwithstanding acquisition of this information, domestic German pension management and investment practices hardly changed. Such is, or was, the power of the institutions under-pinning the social market. Yet this analysis tends to exaggerate the power of the social market; it leaves unexplained the introduction and ready adoption by large German firm of international accounting standards affecting the reporting of corporate financial circumstances with significant implications for employer-sponsored pension benefits.

We suggest in this section that management of large German firms have learnt another important lesson from the Anglo-American world, a lesson that has profound implications for the coherence of the social market and the status of employer-sponsored pension plans. During the 1990s German management, unlike many of their AngloAmerican colleagues, were excluded from the benefits associated with the run-up in global equity markets. ${ }^{\text {xiv }}$ Compensation remained tied to corporate income, denying the relevance of corporate market value. Whereas significant numbers of senior and middle managers in large US firms became wealthy by virtue of their stock options, German managers have been locked-into compensation agreements that balance their traditional interests in income growth with those of workers and shareholders. If, in the early 1990s, stock-options appeared less significant compared to conventional forms of remuneration, by the end of the decade a significant segment of US managers had shifted their aspirations from income growth to wealth creation through company stock market value. ${ }^{\mathrm{xv}}$

These kinds of compensation plans are important in the emerging information and technology sectors concentrated in Silicon Valley (California) and Rt 128/495 Boston (Massachusetts). For many incipient firms and partnerships stock options have had three advantages, shared between the principals of these start-up firms and their employees. Most obviously, stock options are a form of deferred income, allowing low rates of pay to co-exist with the promise of future wealth. For younger workers, especially those with skills and education in demand in the local region, stock options have been used as a reward for commitment. For new ventures, stock options have been an effective mechanism tying younger employees to the firm and its performance over the longer-term with the promise of an initial public offering (IPO), stock-splits and the like. For many ventures, stock options 
have come to replace incentive pay, over-time pay, and pension and related benefit schemes. And yet, like pension benefits, firms rely upon vesting rules and related devices to manage the accumulated value of stock options for individual employees. For the strongest advocates of this form of compensation, stock options have fuelled the transformation of the US economy (2000). ${ }^{\text {xvi }}$

At the same time, stock options have also become very important for large US corporations. Whereas this compensation method was introduced to align the interests of senior corporate officers with their principal shareholders, employee stock options have come to be important in many large S\&P 500 corporations (Laing and Sharpe 1999). In theory, the alignment of interests between senior officers and shareholders is believed to be a better mechanism for driving the growth of corporate market value than conventional compensation packages. Moreover, it is widely believed that stock options encourage risk-taking among senior management otherwise cautious about the consequences of corporate restructuring for their own careers and income. In effect, stock options would redefine the natural partners in any corporate enterprise-from management and labour to management and shareholders. Even if corporate management may not have an interest in the welfare of their stockholders, they also have a profound interest in the "cash-out" value of the firm.

A variety of reasons can be invoked to explain the diffusion of this compensation device down through the corporate hierarchy. Through the 1990s, it became apparent that if corporate management were to remake the US corporation through mergers and acquisitions and the like they would have to buy the loyalty of their immediate functionaries. For a variety of reasons, and the reasons are many and complex, as dividend yields have declined it has become more important to manage corporate market value through year-to-year income flow than income flow in its own right. ${ }^{\text {xvii }}$ Furthermore, it is apparent that the cost accounting of stock options is less than ideal. FASB was not able to introduce reporting rules entirely consistent with the interests of financial markets in properly pricing the true cost of such options. Debate over initial proposals spilled-over into Congress, and through a coalition of "new technology" and "old economy" firms a compromise agreement was forced through on reporting the current value of stock options. Consequently, stock options may be thought to be a partially accounted transfer of wealth to participating employees as it is a benefit to shareholders concerned with the future market value of traded firms. ${ }^{\text {xviii }}$

For German firms, however, operating in the US or in global markets overlapping with Anglo-American firms, stock options have been seen as a vital missing ingredient in 
their management strategies. Whether true or not, stock options are believed to enhance flexibility with respect to market competition and market opportunities, enable greater control over the legions of corporate bureaucrats, and reward risk-taking, notwithstanding

widespread social apprehension about the possible costs of risk-taking. ${ }^{\text {xix }}$ But, of course, management incentives via stock options are only possible if there is a market for corporate control for German firms. And a market for corporate control is only possible if external investors are confident in the value of their investment strategies relative to the traditional claims for privilege made by internal stakeholders (management, labour, and banks). Inevitably, creating a vibrant German market for corporate control requires reporting systems recognised by international investors (hence the importance of International Accounting Standards). And, most importantly, a market for corporate control is only possible if current domestic investors are able to radically reduce their current holdings without incurring significant penalties.

It can be argued, then, that large German firms (their management and principal shareholders) have sought to put in place the institutions and policies necessary to take advantage of an emerging European market for corporate control. As a result of greater financial transparency and accountability, inherited systems of employer-sponsored pensions and retirement income are now essential elements in managing market value. Inevitably, the costs of funding pension liabilities will have to be accounted for and shared between various stakeholders: by workers (in the form of lower relative wages), shareholders (in the form of lower dividends), and perhaps management (in the form of lower shared income). At the same time, the extent to which management is able to develop liability management strategies aimed at protecting the long-term value of the firm, they may also be able to protect their long-term wealth. To do so, however, requires transforming the funding and investment management of German corporate pension assets and liabilities.

\section{Models of Investment Management}

We are now in the position to be able to assess the management of pension assets and liabilities within large German corporations. Having set out the basic assumptions and organising principles underpinning the German model (along the lines suggested by Wolfgang Streeck 1997, amongst others), and having detailed the recent experience of German firms with Anglo-American systems of investment management we can draw contrasts between competing modes of organisation. In this section, we will also use the 
argument made in the previous section about the increasing significance of managing the market value of firm. In fact, we want to show here how changes in the motives of management may ultimately affect the investment management process. ${ }^{\mathrm{xx}}$

\section{Model A: consensus seeking (satisficing)}

In the basic model of the German firm, assumptions were made about the behaviour, motivation, and relationships between management and labour, and management and shareholders. Let us assume that whatever the experience and knowledge of corporate management, we operate in a world so described. Thus we assume that management and labour are joined together in systems of governance, and have as a common goal maintenance of their expected long run income. We also assume, like many other writers on the German model, that the costs of such collaboration (if any) are borne by shareholders in the form of lower dividends. Of course, there are probably two types of shareholders. One type may have preferential status (being an internal principal) while the other type has less status (being denied the benefits of internal knowledge); consequently the costs of such an income distribution policy may weigh more heavily on one type (the latter) than the other (the former).

In the first instance, we consider investment management in relation to pensionskassen assets and liabilities. Here, we can characterise the investment management

process as one of consensus seeking (satisficing) rather than optimising or maximising. Why? For a variety of reasons. It should be readily appreciated that the co-determination process dominates the board appointment process, the decision-making process, and the allocation of risk and uncertainty between those represented on the board of management. Representation on such boards is more often than not a function of institutional career than it is a function of expertise and/or knowledge. Being concerned to maintain expected long-term income, management and labour representatives are highly risk adverse in circumstances where their decisions may affect constituents' share of current and expected corporate income. In particular, worker representatives are assumed very resistant to any changes in their members' contributions (if any) to occupational pensions. In these circumstances, it is widely believed that consensus seeking results in decisions that complement board members' relationships in related organisations (the firm, the union, the region, the industry etc).

In effect, board members are focused upon a negative goal (minimising risk) rather than a positive goal. Having protected against any downside risk, the various interests and 
relationships present on the pensionskassen drive decision-making recognising that the costs of poor decisions are more likely than not to be borne by shareholders. There are significant moral hazard problems in such systems of decision-making, being even more significant in multi-employer industry pensionskassen. March (1994) suggested that in these types of circumstances there are many possible outcomes because there are so many different interests competing for attention. Satisficing is the result of consensus seeking; it is a means of balancing heterogeneous interests and relationships.

\section{Model B: optimising (within constraints)}

Notice that satisficing is, in effect, the default model of decision-making. To get to that point, all we need do is assume a jumble of competing interests largely unorganised or confused by virtue of the background pattern of relationships. There are no doubt firms and industries so easily characterised. In many respects, these are expensive institutions in terms of the costs of decision-making, often poorly managed and poorly focused upon the management of pension assets and liabilities. Whereas some would argue that consensus seeking results in common commitment (Streeck 1997), there does not seem to be any clear reason why this should be necessarily the case. Here, however, we wish to emphasise that optimising (within constraints) is the more likely model of decision-making because government regulations concerning private insurance arrangements loom large in management practice. In fact, it is probably easier to understand decision-making in large German firms and their pensionskassen as a problem of decision-making by rules rather than imagining that decisionmaking is as unencumbered (as implied by the satisficing model).

As pensionskassen are governed and monitored by the insurance regulator, these institutions operate within well-defined boundaries. Not only are there regulations concerning liabilities, for many years, limits have been imposed on the allocation of assets to traded equities, government bonds, and the like. These quantitative limits on asset allocation have effectively narrowed the scope of investment strategy. ${ }^{x i}$ As well, given the importance of actuarial expertise relative to the decision-making process, professional standards are deemed by many to be as important as official regulations. In this context, board members can be thought to act so as to optimise a complex objective function made up of separate goals and objectives related to assets and liabilities. By contrast, unfunded direktzusagen plans are not so burdened by regulations nor are they so exposed to the close scrutiny of external professionals. Indeed, there appear to be few limits on the allocation of direktzusagen assets. 
Rather there is considerable discretion available to firms' treasurers in driving the rate of return on invested assets. Of course, the problem is that most firms' direktzusagen pension assets are co-mingled with corporate assets.

Interestingly, most writers on the theory of decision making distinguish only between satisficing and maximising behaviour. If optimisation is addressed it is seen as a mode of maximising behaviour. In the German case at least, optimisation is a mode of decisionmaking which fits between these two options; it is a form of decision-making that is based upon the observance of external rules and articulated limits. ${ }^{x i i}$ Can management boards maximise within constraints? Would they want to do so given the immediate set of relationships that overlap with and affect board decision-making? It is difficult to answer these two questions in any conclusive manner. Answers to these questions depend upon the circumstances of individual firms and industries. For some firms that have cultivated close relationships with their workers and union representatives, maximising within constraints may be possible; in play may be the joint commitment of management and workers to the financial integrity of the firm rather than their fealty to so-called external relationships.

In this situation, it is important to have advice and experience from outside of the immediate environment. Hence, the experience of the firm in the Anglo-American world can be an important reference point in setting guidelines for decision making. Likewise, the advice of investment consultants separate from the close-knit community of German banking and actuarial consultants may help establish new options and possible relationships.

\section{Model C: maximizing (as if the firm is a global corporation)}

For many German firms, caught within the web of regulations and professional practice, optimising (within constraints) best describes the leading edge of German investment management. By contrast, the maximising model assumes an unfettered decision-making process, and presumes the existence of a clear, unambiguous objective: the highest rate of return on invested assets. Here, as we have seen, the reference point is Anglo-American practice, recognising that over the past decade this model has provided plan sponsors many benefits including contribution holidays, supplements to corporate income, and (presumably) dampened market price volatility. Even so, we should not exaggerate the scope of such a model; there remain important constraints in any such management regime. The relative maturity of defined benefit plans can have significant consequences for the allocation of assets between asset classes. Likewise government regulations relating to minimum funding 
requirements can affect investment decision making. Nevertheless, over the 1990s it is apparent that those Anglo-American firms that based their investment regime on Model $\mathrm{C}$ benefited enormously from the explosive growth of global equity markets.

It is arguable that even if pensionskassen plans have been restricted to optimising or satisficing, direktzusagen plans have had the opportunity to match and mimic AngloAmerican maximisation strategies. Yet it appears that this option has been rarely taken. Until recently, it would seem that direktzusagen assets have been deployed to promote the growth of the firm in ways consistent with the long-term income objectives (growth and stability) of managers and workers. As well, it seems that fixed capital (new plant, technology and infrastructure) has been the ultimate destination for direktzusagen assets. Advanced financial products found in global capital markets have not been favoured investments. Only recently, as many German firms have come to realise that higher rates of return may be found outside the firm and outside of Germany, or in human capital as opposed to physical capital stock, have senior corporate managers come to appreciate the value of alternative options. Indeed, it could be observed that as corporate management have shifted their focus towards the market value of the firm rather than the flow of income, direktzusagen assets have become more valuable just at a time when global financial markets are increasingly aware of the unfunded nature of direktzusagen obligations.

Faced with the heterogeneous interests represented on pensionskassen boards it would seem that direktzusagen plans have greater potential value than pensionskassen plans if funding could be resolved in accordance with the expectations of global financial markets. In effect, this would mean segregating direktzusagen assets and liabilities from corporate assets and liabilities to become an identifiable internal investment organisation. There is evidence that some larger German firms have established these kinds of organisations, being formal mechanisms of managing the entire volume of pension assets and liabilities in accordance with the financial interests of managers and shareholders. Inevitably, to join together these interests with those of workers into a dedicated internal investment institution requires considerable political tact; implicitly, worker representatives are required to support the interests of the firm as it reaches out to the global economy. A subtle shift in loyalty is required, moving from the system of collective bargaining and industrial co-determination and the system of social insurance and welfare to the core objectives of the firm (its managers and shareholders). One possible reward for such a shift in loyalty is enhanced pension and retirement benefits. 
This strategy would re-define the constituency of workers' representatives. At the same time, as the European Commission moves towards an accounting standards regime modelled on the IASC, and as it moves towards European capital market integration by dismantling country-specific quantitative limits on assets classes and cross-border investments, the conditions for a maximisation model are being put in place. Indeed, notwithstanding the debate over various EC proposals to implement a common set of prudential standards and investment guidelines (as developed in De Ryck 1999), it seems increasingly clear that Model $\mathrm{C}$ has strong advocates amongst the larger German firms. The introduction of the Euro has made these types of pan-European regulations more important than ever before. If the market value of the firm is to be the most important management target, Model C is a necessary institutional reform: the market value of the firm can only be maximised if the value of pension assets in relation to liabilities is also maximised.

In these ways, the "up-scaling" of the German economic environment has begun to under-cut the interests of large German firms' management and workers in domestic industrial relations systems. Institutions like employer-sponsored pension and retirement plans once believed to be irrelevant to German social systems have come to the very centre of corporate decision making. Model $\mathrm{C}$ and the funding of pension liabilities are now at the core of the relationship between management and workers. If Model $\mathrm{C}$ does come to dominate, at the limit German workers may be best thought of as corporate debt (bond) holders on par with corporate (equity) shareholders. In that case, management and workers will be joined together in a very different regime of interests and incentives than those that are commonly used to describe German stakeholder capitalism (compare Hutton 1995).

\section{Conclusions}

In this paper, we have focused upon the causes of changing German corporate pension management policies. Recall, in a previous paper we were able to explain much of the history and recent development of pension liability reporting standards. But we were not able to fully account for the apparent shift in German corporate pension policy (Clark, Mansfield, and Tickell 2000). This is an important issue, reflecting common debate in comparative corporate governance and economic geography. It is widely assumed that nation-state institutions and traditions tend to persist in the face of economic institutions located in other jurisdictions. This is not necessarily an absolute argument; many analysts would suggest that any tendency of persistence must be balanced against the forces of competition (Bebchuk and 
Roe 1998). Lock-in does not, and can not, persist forever (Leibowitz and Margolis 1995). Nevertheless, it is difficult to account for instances of rapid institutional change when so much of the literature and national political debate is hostile to the imperatives driving globalisation. Given the paralysis in German public policy concerning the under-funding of social insurance liabilities it may seem surprising that, in the corporate arena at least, there have been such changes in management practice.

Our account of German corporate pension policy has focused upon the motives of corporate management in relation to workers and shareholders. We noted in the previous paper the competitive advantages of access to global financial markets. In this paper, we moved to consider the significance of management interests in remuneration policies that are increasingly focused upon the market value of the firm. To do so, we suggested that large German firms operating in the Anglo-Saxon world during the 1990s learnt a great deal about advanced financial management; specifically, they learnt the value of maximisation strategies. In order to make this point, we emphasized competing corporate and pension investment management practices differentiating between three models: maximisation, optimisation, and satisficing. For German corporate management, knowledgeable about the costs and benefits of competing investment management practices, one lesson of the 1990s was that the satisficing model is a most expensive option whether pension liabilities are funded, unfunded or under-funded. In an integrated global financial market with common accounting rules, the implications of pension liabilities for corporate market value are all too clear.

To sustain our argument, we emphasized management motives. In particular, it was argued that the historical agreement between management and labour to share corporate revenue within and without the firm is slowly breaking down. Corporate management has less of an interest in sharing current and expected income with labour than it has an increasing interest in generating their own wealth in the form of stock options linked to the market value of the firm as determined in global financial markets. This is a very different model of corporate governance than that which dominated, and still dominates in many sectors and small and medium firms, German political economy for more than fifty years (see also Pistor 1999).

We must be careful, however, not to exaggerate our argument. We do not mean to suggest that stock options are the most important issue in German corporate governance. There remain important political barriers to the full implementation of such systems of 
executive compensation. The current coalition government has found it difficult to introduce the necessary reforms of social insurance and the necessary revisions of the tax code that would either promote private employer-sponsored pensions or the trading of corporate stock. In this context, any widespread introduction of stock options would presuppose political agreement on many issues still outstanding in the public arena. On the other hand, it seems to us that the prospect of some form of executive compensation based on the market value of the firm now drives the management of large German firms. Inevitably, in this context, pension liabilities have become an important part of management corporate strategy. Given the experience in the Anglo-American world, the funding and management of inherited pension obligations is an essential ingredient in any plans aimed at maximising the market value of the firm.

There maybe, of course, other motives important in understanding recent corporate pension initiatives. We have surely only touched the surface of a complex issue. Witness recent studies on hostile take-overs in Germany (Jenkinson and Ljungqvist 1999) and the dissembling of the German model (Berndt 1998). Even so, in the previous paper we were unable to sustain a link between the adoption of international accounting standards and German corporate governance in circumstances unrelated to the development of those standards. Here, we have argued that the adoption of international accounting standards given significant corporate pension liabilities can be traced back to a basic issue deeply embedded in German political economy: the changing relationship between management, workers, and shareholders. We have suggested that this relationship is being rewritten within large firms, even if debate over the proper form of this relationship has been stymied in the public arena. It is as if large firms have been made exceptional--as if German national interest in global economic champions has necessitated their leaving the complex array of interrelated national social systems for the global market place.

Here, then, are two important implications for the future of employer-sponsored private pensions in Germany. If large German firms are to be allowed to float free of the core systems underpinning German social structure, mimicking and matching their AngloAmerican competitors, questions must be raised about the long-term future of defined benefit pensions. As they move into the world of financial accountability and transparency, the funding and management of inherited pension liabilities loom large as issues likely to distinguish German firms from Anglo-American firms. In the US context, and increasingly in the UK and elsewhere, employer-sponsored defined benefit plans are slowly giving way to 
defined contribution plans and other more exotic individual retirement accounts. In this respect, once German firms are able to institute management regimes to discount the value of inherited liabilities, what would be the limits of any corporate policy designed to shift pension risk and liability to employees? At issue, is the extent to which workers' interest in expected long-term income can be transformed into a share of short-term corporate wealth.

One should not underestimate German workers' risk aversion; this is deeply embedded in the relations between management and labour as well as in the political arena. It is apparent, however, that at a moment in time when there is considerable debate about the possible means of funding retirement the recent experience of large German corporations provides important lessons for German political economy. If international accounting standards are to be applied to all traded European firms then the implied burden of any policy designed to encourage the provision of employer-sponsored pensions may have to be shared between the social partners. Otherwise, whatever the tax incentives introduced to encourage private provision, it seems unlikely that German employers would readily embrace a model of pension provision which carries with it a liability risk fully exposed to the market of corporate control. Perhaps there are alternatives, including industry-wide systems of mandatory pension provision like the Dutch model. Such a system would naturally map onto existing systems of labour management and corporate governance. As we have seen, however, such systems carry with them significant risks of moral hazard.

In the end, the implication of our research on German employer-sponsored pensions is that any private alternative to the existing system of social insurance must be a funded system of private provision. Existing unfunded direktzusagen (book reserve) and under-funded pensionskassen (mutual insurance) defined benefit systems will not survive the harsh gaze of globalisation. In that case, one of the most important pillars underpinning the financial structure of the German model will have been rendered obsolete. The question that remains is the extent to which such a profound change in corporate financial structure will affect labourmanagement relationships and German society in general. 


\section{Endnotes}

\section{References}

Aggarwal, R. and A. Samwick. 1999. Executive compensation, strategic competition, and relative performance evaluation: theory and evidence. Journal of Finance 54, 1999-2044

Andre, T. J. 1998. Cultural hegemony: the exportation of Anglo-Saxon corporate governance ideologies to Germany. Tulane Law Review 73, 69-171

Baird, D. G. and R. C. Picker. 1991. A simple non-cooperative bargaining model of corporate reorganizations. Journal of Legal Studies 20, 311-349

Bebchuk, L. and M. Roe. 2000. A theory of path dependence in corporate governance and ownership. Stanford Law Review (forthcoming)

Bennett, P. and G. L. Clark. 2000. The Dutch model of sector-wide supplementary pensions: fund governance, finance and European competition policy. Working Paper 00-03. Oxford: School of Geography and the Environment, University of Oxford

Berndt, C. 1998. Ruhr firms between dynamic change and structural persistence globalization, the 'German model' and regional place-dependence. Transactions NS 23, 331352

Bicchieri, C. 1993. Rationality and Coordination. Cambridge: Cambridge University Press

Binmore, K. and P. Dasgupta. Eds. 1989. The Economics of Bargaining. Oxford: Blackwell

Bliss, M. and M. J. Flannery. 2000. Market discipline in the governance of US bank holding companies: monitoring vs. influencing. WP-00-03. Chicago: Research Department, Federal Reserve Bank of Chicago

Borsch-Supan, A. 2000a. A model under siege: a case study of the German retirement insurance system. Economic Journal 110, 24-40

Borsch-Supan, A. 2000b. A blue print for Germany's pension reform. Mannheim: Department of Economics, University of Mannheim

Camerer, C. and M. Weber. 1992. Recent developments in modeling preferences: uncertainty and ambiguity. Journal of Risk and Uncertainty 5, 325-370

Clark, G. L. 1994. Strategy and structure: corporate restructuring and the scope and characteristics of sunk costs. Environment and Planning A 26, 9-32

Clark, G. L. 1998. Stylized facts and close dialogue: methodology in economic geography. Annals, Association of American Geographers 88, 54-73

Clark, G. L. 2000. Pension Fund Capitalism. Oxford: Oxford University Press 
Clark, G. L., D. Mansfield, and A. Tickell. 2000. Accounting standards and German supplementary pensions: the emerging framework underpinning global finance. Working Paper 00-05. Oxford: School of Geography and the Environment, University of Oxford

Demsetz, H. 1983. The structure of ownership and the theory of the firm. Journal of Law and Economics 26, 375-393

De Ryck, K. 1999. Rebuilding Pensions: Security, Efficiency, Affordability. Recommendations for a European Code of Best Practice for Second Pillar Pension Funds. Brussels: European Commission

Deutsche Bank. 1996. From Pension Reserves to Pension Funds: An Opportunity for the German Financial Market. Special Study. Frankfurt am Main: DB Research Management

Deutsche Bank. 1999. Pension Funds for Europe. Special Study. Frankfurt am Main: DB Research Management

Disney, R. 2000. Crises in public pension programmes in OECD: what are the reform options? The Economic Journal 110, 1-23

Easterbrook, F. and D. Fischel. 1990. The Economic Structure of Corporate Law. Cambridge MA: Harvard University Press

Feldstein, M. 2000. Preface: the NBER-Sloan project on productivity change. In NBER/Sloan Project Report on Industrial Technology and Productivity. Cambridge MA: NBER, pp. ii-iv.

Franks, J. and C. Mayer. 1998. Bank control, takeovers, and corporate governance. In Comparative Corporate Governance: The State of the Art and Emerging Research. Edited by K. J. Hopt, H. Kanda, M. J. Roe, E. Wymeersch, and S. Prigge. Oxford: Oxford University Press, pp. 641-658

Gertler, M. 2000. Convergence, scale and learning: industrial practices of German firms in North America. Mimeo. Toronto: Department of Geography, University of Toronto

Helper, S. 2000. Economists and field research: "you can observe a lot just by watching." American Economic Review Vol. 90(2) 228-232

Holderness, C. G., R. S. Kroszner, and D. Sheehan. 1999. Were the good old days that good? Changes in managerial stock ownership since the great depression. Journal of Finance 54, $435-470$

Hopt, K. J., H. Kanda, M. J. Roe, E. Wymeersch, and S. Prigge. Eds. 1998. Comparative Corporate Governance: The State of the Art and Emerging Research. Oxford: Oxford University Press

Huebeck, K. and G. Baum. 1998. New types of pension fund in Germany. Benefits and Compensation International (Nov) 2-6 
Hutton, W. 1995. The State We're In. London: Jonathon Cape

Jenkinson, T. and A. Ljungqvist. 1999. The role of hostile stakes in German corporate governance. Mimeo. Oxford: Department of Economics, University of Oxford

Kluth, M. F. and J. Andersen. 1999. Globalisation and financial diversity: the making of venture capital markets in France, Germany and UK. In Innovation Policy in a Global Economy edited by D. Archibugi, J. Howells and J. Michie. Cambridge: Cambridge University Press, pp. 120-38

Koenig, P. and E. van der Lende. 1999. The pension system of "Germany PLC." Global Pensions Quarterly (October/November). London: Morgan Stanley Dean Witter

La Porta, R., F. Lopez-de-Silanes, A. Shleifer, and R. Vishny. 1997. Legal determinants of external finance. Journal of Finance 52, 1131-50

La Porta, R., F. Lopez-de-Silanes, A. Shleifer, and R. Vishny. 2000. Agency problems and dividend policies around the world. Journal of Finance 55, 1-33

Laing, J. N. and S. Sharpe. 1999. Share repurchases and employee stock options and their implications for S\&P 500 share retirements and expected returns. Mimeo. Washington DC: Division of Research and Statistics, Federal Reserve Board

Liebowitz, S. and S. Margolis. 1995. Path dependence, lock-in, and history. Journal of Law, Economics and Organization 7, 205-226

Logue, D. E. and J. S. Rader. 1998. Managing Pension Funds: A Comprehensive Guide to Improving Fund Performance. Boston: Harvard Business School Press

Luhmann, N. 1995. Social Systems. Translated by J. Bednarz with D. Baecker. Stanford: Stanford University Press

March, J. 1994. A Primer on Decision Making: How Decisions Happen. New York: Free Press

McConnell, P., J. Pegg and D. Zion. 1999. Accounting Issues: Retirement Benefits Impact Operating Income. New York: Bear Stearns

Mitchell, O. 1998. Administrative costs in public and private retirement systems. In Privatizing Social Security edited by M. Feldstein. Chicago: University of Chicago Press, pp. 403-52

Myers, S. 2000. Outside equity. Journal of Finance 55, 1005-1037

NIESR. 1997. Capital Market Liberalisation. The Single Market Review. Sub-series III: Dismantling of Barriers. Luxembourg: Office of Official Publications of the European Communities 
O'Sullivan, M. 1998. The political economy of corporate governance in Germany. Working Paper 226. Bard College, Jerome Levy Economics Institute

Pistor, K. 1999. Co-determination in Germany: a socio-political model with governnance externalities. In Employees and Corporate Governance edited by M. Roe and M. Blair. Washington DC: Brookings Institutions, pp

Queisser, M. 1996. Pensions in Germany. Mimeo. Washington DC: World Bank

Reynaud, E. 2000. Introduction and summary. In Social Dialogue and Pension Reform edited by E. Reynaud. Geneva: International Labor Organisation, pp. 1-10

Roe, M. J. 1998. German co-determination and German securities markets. In Comparative Corporate Governance: The State of the Art and Emerging Research. Edited by K. J. Hopt, H. Kanda, M. J. Roe, E. Wymeersch, and S. Prigge. Oxford: Oxford University Press, pp. 361372

Rurup, B. 2000. The future of the German pension system: stabilization of contributions by a mandatory savings plan. Mimeo. Cambridge MA: National Bureau of Economic Research

Simon, H. 1956. Rational choice and the structure of the environment. Psychological Review 63, 129-118

Schmahl, R. 1997. The public-private mix in pension provision in Germany: the role of employer-based pension arrangements and the influence of public activities. In Enterprise and the Welfare State edited by M. Rein and E. Wadensjo. Cheltenham: Edward Elgar, pp. 99-148

Shleifer, A. 2000. Inefficient Markets: An Introduction to Behavioural Finance. Oxford: Oxford University Press

Steinmeyer, H-D. 1996. Consistency between contribution relief and the European legislation on competition. In Social Protection and the Single Market. The Evolution of the Social Security Systems and Free Circulation: Problems and Perspectives. Rome: CEIS Tor Vergata, pp. 87-98

Streeck, W. 1997. German capitalism: does it exist? Can it survive? In Political Economy of Modern Capitalism edited by C. Crouch and W. Streeck. London: Sage, pp. 33-54

Swyngedouw, E. 2000. Elite power, global forces, and the political economy of 'glocal' development. In The Oxford Handbook of Economic Geography edited by G. L. Clark, and M. F. Feldman and M. Gertler. Oxford: Oxford University Press, pp. 541-558

Towers Perrin. 2000. Another Year of Big Gains for Pension Plans. New York (available at http://www.towers.com)

Watson Wyatt. 2000. Pension income: here today, here tomorrow. Available at www.watsonwyatt.com/homepage/us/news/insid.../2000_05_03.as 
Weiss, M. 1995. Labour Law and Industrial Relations in Germany. Deventer: Kluwer Publishers

Williams, D. and R. Reid. 2000. The new economy: the third industrial revolution, productivity, profits and equity markets. London: Donaldson, Lufkin \& Janrette 
Table 1 German employer-sponsored occupational pensions percentage share of total retirement income (1996) assuming 35 years of service

\begin{tabular}{|c|c|c|c|}
\hline Firm & $\begin{array}{c}\text { Employer } \\
\text { Contributions } \\
\end{array}$ & $\begin{array}{c}\text { Employee } \\
\text { Contributions } \\
\end{array}$ & $\begin{array}{c}\text { Total } \\
(\%)\end{array}$ \\
\hline BASF & 24 & 4 & 28 \\
\hline Bayer & 25 & 3 & 28 \\
\hline Bosch & 26 & - & 26 \\
\hline Daimler Benz & 30 & - & 30 \\
\hline Degussa & 25 & 3 & 28 \\
\hline Henkel & 33 & - & 33 \\
\hline Hoechst & 27 & 4 & 31 \\
\hline Merck & 35 & - & 35 \\
\hline Siemens & 27 & - & 27 \\
\hline
\end{tabular}

Note:Assuming a defined benefit pension without regard to the particular institution managing pension plan assets and liabilities 
Table 2 US pension and related income plan experience of German Dax-listed corporations

1997-1999, excluding death, disability, health and dental care plans

\begin{tabular}{|c|c|c|c|c|c|c|c|c|}
\hline \multirow[t]{3}{*}{ Firm } & \multirow{3}{*}{$\begin{array}{l}\text { No. of } \\
\text { Plans }\end{array}$} & \multicolumn{5}{|c|}{ Pension and Retirement Plans } & \multirow{3}{*}{$\underline{\text { Union }}$} & \multirow{3}{*}{$\begin{array}{l}\text { Acquired } \\
\text { Firms }\end{array}$} \\
\hline & & \multirow{2}{*}{ DB } & \multicolumn{4}{|c|}{ Defined Contribution } & & \\
\hline & & & 401(K) & Profit & Savings & Flexible & & \\
\hline Adidas & 4 & & $\sqrt{ }$ & & $\sqrt{ }$ & $\sqrt{ }$ & & $\sqrt{ }$ \\
\hline Allianz & 2 & & $\sqrt{ }$ & & & & & \\
\hline BASF & 5 & $\sqrt{ }$ & $\sqrt{ }$ & & $\sqrt{ }$ & & $\mathrm{u}$ & $\sqrt{ }$ \\
\hline Bayer & 14 & $\sqrt{ }$ & $\sqrt{ }$ & $\sqrt{ }$ & $\sqrt{ }$ & $\sqrt{ }$ & $\mathrm{u}$ & $\sqrt{ }$ \\
\hline $\begin{array}{l}\text { Bayerische Hypo- } \\
\text { und-Vereinsbank }\end{array}$ & 1 & & $\sqrt{ }$ & $\sqrt{ }$ & $\sqrt{ }$ & & & \\
\hline BMW & 25 & & $\sqrt{ }$ & $\sqrt{ }$ & $\sqrt{ }$ & $\sqrt{ }$ & $\mathrm{u}$ & \\
\hline Commerzbank & 7 & $\sqrt{ }$ & $\sqrt{ }$ & & $\sqrt{ }$ & $\sqrt{ }$ & & \\
\hline Daimler & 1 & & $\sqrt{ }$ & & & & & \\
\hline Daimler/Chrysler & 10 & $\sqrt{ }$ & $\sqrt{ }$ & & $\sqrt{ }$ & & $\mathrm{u}$ & $\sqrt{ }$ \\
\hline Degussa & 3 & $\sqrt{ }$ & $\sqrt{ }$ & & $\sqrt{ }$ & $\sqrt{ }$ & & \\
\hline Deutsche Bank & 3 & $\sqrt{ }$ & $\sqrt{ }$ & $\sqrt{ }$ & $\sqrt{ }$ & $\sqrt{ }$ & & \\
\hline Deutsche Telecom & 2 & $\sqrt{ }$ & $\sqrt{ }$ & & & & $\mathrm{u}$ & \\
\hline Dresdner Bank & 6 & $\sqrt{ }$ & $\sqrt{ }$ & $\sqrt{ }$ & $\sqrt{ }$ & $\sqrt{ }$ & & $\sqrt{ }$ \\
\hline Fresenius & 1 & & & & $\sqrt{ }$ & & & \\
\hline Henkel Corp & 17 & $\sqrt{ }$ & $\sqrt{ }$ & $\sqrt{ }$ & $\sqrt{ }$ & $\sqrt{ }$ & $\mathrm{u}$ & $\sqrt{ }$ \\
\hline Linde Ent. & 9 & & $\sqrt{ }$ & $\sqrt{ }$ & & $\sqrt{ }$ & & $\sqrt{ }$ \\
\hline Lufthansa & 5 & $\sqrt{ }$ & $\sqrt{ }$ & & & & $\mathrm{U}$ & \\
\hline Mannesmann & 10 & $\sqrt{ }$ & $\sqrt{ }$ & & $\sqrt{ }$ & $\sqrt{ }$ & $\mathrm{U}$ & $\sqrt{ }$ \\
\hline Preussag & 2 & & $\sqrt{ }$ & $\sqrt{ }$ & & $\sqrt{ }$ & & \\
\hline RWE & 1 & $\sqrt{ }$ & & & & & & \\
\hline Schering Corp & 5 & $\sqrt{ }$ & $\sqrt{ }$ & $\sqrt{ }$ & $\sqrt{ }$ & $\sqrt{ }$ & & $\sqrt{ }$ \\
\hline Siemens & 46 & $\sqrt{ }$ & $\sqrt{ }$ & $\sqrt{ }$ & $\sqrt{ }$ & $\sqrt{ }$ & $\mathrm{u}$ & $\sqrt{ }$ \\
\hline Thyssen & 14 & $\sqrt{ }$ & $\sqrt{ }$ & $\sqrt{ }$ & $\sqrt{ }$ & $\sqrt{ }$ & $\mathrm{u}$ & $\sqrt{ }$ \\
\hline Krupp & 2 & $\sqrt{ }$ & $\sqrt{ }$ & $\sqrt{ }$ & $\sqrt{ }$ & $\sqrt{ }$ & & $\sqrt{ }$ \\
\hline Volkswagen & 11 & $\sqrt{ }$ & $\sqrt{ }$ & $\sqrt{ }$ & $\sqrt{ }$ & $\sqrt{ }$ & & $\sqrt{ }$ \\
\hline
\end{tabular}

Source: freeERISA.com

Notes: For definitions of these various different types of pension and retirement income plans see the web site www.freeERISA.com/info/glossary.asp Notice there are many different versions of defined contribution plans. For example, flexible benefit plans sometimes called cafeteria plans rely upon an IRS tax provision, and may or may not supplement other benefits. A savings plan is a type that defined contribution plans in which participants may make discretionary contributions either matched or partially matched by their employers. Normally such contributions are made after tax rather than before tax (the preferred basis of pension fund contributions). 
Table 3 Summary of Bayer Corp. employer-sponsored US pension plans (1997)

\begin{tabular}{|c|c|c|c|c|c|c|c|c|c|}
\hline \multirow{2}{*}{$\begin{array}{l}\text { Plan } \\
\text { No. }\end{array}$} & \multirow{2}{*}{$\begin{array}{l}\text { Plan } \\
\text { Type }\end{array}$} & \multicolumn{3}{|c|}{ Participants } & \multicolumn{2}{|c|}{ Year end $(\$ m l)$} & \multirow{2}{*}{$\begin{array}{c}\text { Year-end } \\
\text { Investment } \\
\text { Return }(\%)\end{array}$} & \multirow{2}{*}{$\begin{array}{c}\text { Net }(\$ \mathrm{ml}) \\
\text { Income }\end{array}$} & \multirow{2}{*}{$\begin{array}{c}\text { PBGC } \\
\text { Covered }\end{array}$} \\
\hline & & Vested & $\begin{array}{c}\text { Non- } \\
\text { Vested }\end{array}$ & Retirees** & Assets & Expenses & & & \\
\hline $003 *$ & DB & 216 & 120 & 118 & 7.27 & 0.23 & 31.4 & 1.39 & $\sqrt{ }$ \\
\hline $006^{*}$ & DB & \multicolumn{3}{|c|}{ Fewer than 100 participants } & 0.97 & 0.014 & 15.3 & 0.22 & $\sqrt{ }$ \\
\hline $009 *$ & DB & \multicolumn{3}{|c|}{ Fewer than 100 participants } & 1.13 & 0.006 & 19.3 & 0.26 & $\sqrt{ }$ \\
\hline $010^{*}$ & DB & 231 & 176 & 102 & 13.67 & 0.241 & 16.3 & 2.15 & $\sqrt{ }$ \\
\hline 015 & DB & 121 & 7 & 60 & 2.39 & 0.039 & 51.8 & 0.48 & $\sqrt{ }$ \\
\hline 019 & $401(\mathrm{k})$ & 14,541 & 4,175 & 12,696 & 1,946 & 44.37 & 19.1 & 286.51 & $\sqrt{ }$ \\
\hline 021 & $401(\mathrm{k})$ & 588 & 66 & 242 & 73.29 & 2.15 & 18.0 & 17.79 & $\sqrt{ }$ \\
\hline 023 & N/A & & & & & & & & \\
\hline 025 & $401(\mathrm{k})$ & 384 & 55 & 6 & 7.77 & 0.411 & N/A & 3.05 & $\sqrt{ }$ \\
\hline
\end{tabular}

Source: freeERISA.com

Notes: *Union identified as representing covered workers.

**Including separated employees with deferred entitlements.

i). Throughout this paper, we use these three terms to represent agents' economic behaviour (in general) and the behaviour of management, labour and shareholders in particular. In latter sections, close attention is paid to their definitions and distinctions. For the moment, it is sufficient to suppose that maximisation refers to seeking the best possible outcome notwithstanding the existence of known cognitive and organisational barriers to achieving that outcome. Optimisation can be thought to refer to choosing the best option for achieving the most desired result consistent with known constraints. By contrast, satisficing may be thought to refer to decision making that has as its goal a satisfactory outcome if not the best outcome or the optimal result. Here, we use a set of distinctions first introduced by Simon (1956) and refined further to identify a gap between maximisation and optimisation.

ii. Whereas it might have been suggested some years ago that fieldwork was the exclusive domain of economic geographers, mainstream economists have come to realise the special insights and knowledge that can come from this kind of analysis. See Helper's (2000) paper, and the results of the joint NBER/Sloan sponsored project on industrial technology and productivity using "site based research". Martin Feldstein (2000) President of the NBER provides a helpful overview to the project and the value of what he terms as "pin factory" visits (referencing Adam Smith). 
iii. Industry and academic commentaries have also focused upon the economic costs of social insurance for industrial competitiveness (Steinmeyer 1996), and the long-term unsustainable financial burdens of the current Pay-As-You-Go (PAYG) system (see Borsch-Supan 2000a). Some analysts have suggested radical reform of social insurance, including the introduction of notional accounts, partial funding and capped benefits (Borsch-Supan 2000b). There are also those that advocate the promotion of tax-preferred employer-sponsored occupational pensions, matching and mimicking the claimed desirable attributes of Anglo-American defined contribution pension plans (Deutsche Bank 1996).

iv/. This point is made by numerous authors. See, for example, Wolfgang Streeck (1997, p. 37) where he suggests that firms "are social institutions, not just networks of private contracts or the property of the shareholders. Their internal order is a matter of public interest and are subject to extensive social regulation, by law and industrial agreement. Also, managers of large German firms face capital and labour markets that are highly organised, enabling both capital and labour to participate directly in the everyday operation of the firm and requiring decisions to be continuously negotiated."

$\%$. The idea that such coverage rates are too low or too narrowly focused on particular segments of German industry is surely a reflection of the more general claim on behalf of the comprehensive nature of social insurance. These coverage rates are not so unusual or limited if compared to the Anglo-American world. See Clark (2000) on UK and US coverage rates, noting the bias towards large firms, unionised industry, and manufacturing.

vi/. We do not wish to over-emphasise the significance of corporate private pensions. There are good reasons why much of the literature focuses upon the German public pension system - as many studies show, statutory pension insurance dominates the provision of retirement income (measured according to the value of benefits). On the other hand, there is considerable interest in the current role of employer-sponsored pensions and in their possible long-term role in providing benefits if statutory pension insurance may be unable to play the same role as in the past. For further detailed analysis of the German pension system and a proposal to introduce a mandatory savings system see the recent paper by Rurup (2000). On the relationship between public and private pension provision in Germany see Schmahl (1997).

vii/. Surely these are not controversial assumptions, at least in economic geography (Clark 1994). In economics, however, such assumptions cut against the possibility of creating universal axioms consistent with the efficient market hypothesis. While recognising that there may well be instances of 
behaviour that reflect the immediate context in which action takes place, many economic theorists are loath to recognise that context may have a systematic effect. For a detailed analysis of this point in the context of the performance of financial markets see Shleifer (2000) on behavioural finance.

viii. There are various explanations of these arrangements, many of which emphasize the deliberate fragmentation of union and management powers characteristic of post war Germany (see O'Sullivan 1998).

ix/. See, for example, Edwards and Mayer (1998) on the dimensions of cross-holdings of shares in Germany.

\% Assumptions five and six may be disputed by some readers. Furthermore, the concentration of much of the academic literature on the formal powers of supervisory boards may reinforce, for some readers, a sense of unease about the presumed scope of powers attributed to German corporate management (see Weiss 1995). We recognise that our emphasis on management as opposed to supervisory boards will be controversial. Even so, we take heart from recent research on German corporate governance. Pistor's (1999) paper is similarly more focused on the effective powers of management in circumstances where global competition has given management the opportunity to remake their relationships with both workers and shareholders.

xi $/$ In this vein, Reynaud $(2000,8)$ suggested that the value of international comparisons was "not to import ready-made solutions from abroard to solve problems faced at (the) domestic level." Going further, he said "national pension systems are the product of the societies concerned and inevitably reflect the series of specific characteristics, especially concerning the relationship between the state and society, political traditions, industrial relations, structure of the economy, and perceptions of justice and equality."

xii/. This data is made available on a free web-site where US pension and retirement income benefit information based on Form 5500. That web-site utilises official government information but is not affiliated directly or indirectly with the US government. The web address is freeERISA.com

xiii/. See also a report by industry analysts Towers Perrin (2000). They show that in 1999 the reported earnings of 25 of the 30 firms included in the Dow Jones Industrial Index were positively affected by pension income (including reductions in pension contributions) derived from defined benefit programmes. As well, reported pension liabilities were smaller because these same firms were able to 
increase their discount rates (used to determine the present value of obligations). The 1999 effect of DB pension plans was stronger than even the 1998 effect on net corporate income.

${ }^{\mathrm{xiv}} /$. We should also recognise that German firms most affected by this issue have been those that have acquired or have established Anglo-American firms staffed by UK or US nationals. The problem for such firms has been to attract and retain the best staff when, in fact, German firms have been resistant to the introduction of stock options as part of senior managers' compensation packages. Worse still have been instances when German firms have introduced stock-options for UK or US nationals but have restricted access to such compensation to their German staff. The internal tensions occasioned by such inequities between senior managers have made the management process across systems of corporate governance and financial markets even more difficult than heretofore recognised in the literature (compare Hopt et al. 1998).

${ }^{\mathrm{xv}} /$. It should be noted, however, that although managerial stock ownership has increased in recent years, it remains true that many other forms of executive compensation are used to regulate the principal-agent relationship. See the study by Holderness et al. (1999) on trends in managerial ownership of US corporations since the Great Depression of the twentieth-century.

${ }^{\mathrm{xvi}}$. Still, we should take care not to over-emphasise the significance of stock-options in the US economy. The fact that it is important in Silicon Valley does not mean that it is widely used in other sectors and regions of the US economy. Witness, for example, the comment made by Paul Osterman (1999, p. 15) that "Silicon Valley is a white collar craft labour market in which very skilled workers move easily from place to place aided not by crafty unions but by informal networks. The useful lesson to draw from the valley is that in a labour market characterised by job turnover highly skilled people whose capacities are in short supply will do fine.... Just as no one believes that the labour market for sports stars or Hollywood actors typifies the circumstances of most Americans, nor should we believe that the success of one stratum in the Silicon Valley presages success for everyone."

xvii/. Actually, the question of executive compensation is far more complicated than these brief comments may suggest. Recent research suggests that performance related compensation is, more often than not, less about relative performance (comparing corporations' performance) and more about individual firm performance or industry performance. Industry competition, corporate strategy, and inter-firm interaction all complicate any assumption that relative firm performance is the obvious benchmark against which to assess management competence (Aggarwal and Samwick 1999). In other words, stock options may be seen as an issue of wealth allocation between competing stakeholders in the modern firm. 
xviii . For details of the FASB standard accounting for stock based compensation see their October 1995 (154-C) Statement of Financial Accounting Standards No. 123. In that publication the Board recommends rather than requires that firms report stock based employee compensation using a fair value method. It is suggested that this method is preferable to previous methods in that employee compensation would be measured "at the grant date based on the value of the award... recognised over the service period". The FASB goes into some detail about the controversy surrounding their proposal and the compromise forced upon it by Congress. It remains a highly contentious issue, witness the controversy surrounding a very similar proposal by the UK Accounting Standards Board (July 2000). In the end, it seems that this issue may have to be resolved at the International Accounting Standards Committee.

xix $/$ Further more, it might also be suggested that German management anticipate the flow-on from the US and the UK of the technological benefits for labour productivity associated with the "new economy". See the recent report by Williams and Reid (2000) on the consequences of the "new economy" for Europe.

${ }^{x x} /$. There will be aspects of this discussion unfamiliar to an Anglo-American audience. In previous work, Clark (2000) set out the structure of the Anglo-American investment management industry and the market for financial services. The Anglo-American pension fund industry relies heavily upon the market for services typically internal to German firms and their banking partners. Whereas investment officers and pension fund trustees are responsible for discriminating amongst competing service providers, these kinds of decisions are rarely made in German firms and their pensionskassen.

${ }^{x x i}$. Details on the nature of these regulations for German investment policy are to be found in Heubeck and Baum (1998). Their article is devoted to (then) recent proposals for a new "concept for occupational pension financing", combining aspects of the Anglo-American world (including the UK and the US) with solvency protection and independence from plan sponsors. As is well appreciated, these types of proposals have come at an increasing rate over the past few years, being aimed at Germany, other continental European countries and the pan-European environment.

xxii/. It might be argued, of course, that Anglo-American pension fund trustees are similarly obsessed with rules. If that is the case, as suggested in part in Clark (2000), then it should be understood that rules as constraints more often than not dominate German institutions. 